\title{
(China Collective Negotiation in COVID-19: What aße We learn from a Comparative Analysis of China, the Rasearch House United States and Germany
}

\section{Xiaohan Sun}

Assistant Professor, Law School, Xiamen University, Xiamen, Fujian, CHINA

\begin{abstract}
Labor conflicts can be solved by an efficient collective bargaining system with consensus-based. Since the economic uncertainty caused by COVID-19, employers have been shut down or have had to reduce operations drastically and many employers want to furlough or dismiss employees under certain circumstances. Meanwhile, many workers have lost income. Since Chinese workers have returned to worksite in March 2020, labor unrest has spread out in order to ask for wage arrears in manufactory, construction, and service sectors in terms of strikes map from China Labor Bulletin. The paper targets on three different countries with top economies, and examines its bargaining models to keep industrial peace. The paper argues that China bargaining model under state-control strongly depends on government intention for intervention where there is a labor conflict. The system less focuses on selfgovernance which may result in a hard time to maintain industrial resources, even though the state issued the related polies to highly encourage companies to hold a negotiation before laying off workers, reduce wages or work time in order to be employed. While less polices and China traditional commandand-control regulation model could not provide an efficient approach to relief labor unrest in the pandemic, Germany bargaining model is more flexible to provide an example for new governance and co-determination. Also, bargaining model with sector-level reforms could do more for the United States private sectors in order to corporation instead of adversarialism. From comparison of three collective bargaining models, the paper concludes the approaches to protect workers' right from global perspectives.
\end{abstract}

Keywords: globalization, comparative analysis, collective bargaining, strikes, covid-19

\section{The Collective Bargaining Model in China, the United States, Germany CHINA}

The Chinese Collective bargaining model is a bipartite bargaining which focuses on the private sector. There is a two-stage system to reach collective agreements on the theory of state corporatism: first, the negotiation of company/sectoral level collective agreements; second, the labor administrative agency should review and confirm the collective contract to ensure the contract is not against labor laws and regulations.

The Trade Unions Law requires that firms with more than twenty-five employees shall establish grassroots trade union committee, and a firm with less than twenty-five employees can establish a grassroots trade union committee individually or the firm can join with another firm to establish the grassroots trade union committee. The word "shall" means may and will in this article. Moreover, Chinese workers are represented by a grassroots trade union or a certain group of democratic recommendation by employees at the company level in the process of negotiation in terms of the Provisions of Collective Contracts. That is to say, a negotiation still can be triggered by a certain group of employees through the democratic process even without an establishment of grassroots trade union. Establishment of grassroots trade union is not mandatory before the collective bargaining. Either workers" representative or an employer can make a written request for collective bargaining, the non-moving party shall not refuse collective bargaining unless there are reasonable and justifiable reasons to do so. However, if there is a labor dispute for rights in the process of an 
existing collective contract, only the grassroots trade union can be employees' representative in labor arbitration and adjudication.

Generally, there are three levels of collective negotiation: company, regional, and sectoral. The Labor Contract Law allows collective agreements on the regional or sectoral level, and the agreements can be reached by trade unions and employees' representatives in certain industries, such as construction, mining, and food service industry. These agreements, however, only exist on the areas below the county level of administrative region in terms of the Labor Contract Law. The Labor Contract Law clarifies that collective agreements on the regional or sectoral level would be binding on all firms and employees within their region/sector, and collective agreements at the company level would be binding on all employees and the employer. In practice, almost all collective bargaining was occurred at the company level.

As for a company-level collective agreement, the collective agreement draft was made by the workers' representative and the employer. After that, the collective agreement shall be discussed with the Employee Representative Congress/employees in a meeting that at least two thirds of employee representatives/employees participated. The final draft of collective agreement shall get consent to half of the employee representatives/employees in the meeting, and then it shall be signed by both parties. The final draft shall be reviewed by the local Labor and Social Security Administrative agency within fifteen days with regard to three aspects: parties' competency, legitimate bargaining procedures, and legality of the agreements' contents. Once the agreement is approved of the legality check, it would take effect. As for a sectoral or regional collective agreement, the draft of the agreement made by the trade union and the employers' associations shall be reviewed and checked for legality by the local Labor and Social Security Administrative Agency within fifteen days. If the agreement does not receive opposition to the administrative agency, it would come into force. In addition, the Labor Contract Law prohibits individual employment contracts for making working conditions and remuneration lower than the standards written in the collective agreement.

\section{UNITED STATES}

U.S. Collective bargaining is conducted primarily on a single-employer basis, with the employer and the employees' representative determining the conditions of employment. A collective agreement is a result of collective bargaining. The union is the "exclusive representative" of the employees. Labor laws, regulations, and judicial decisions control the behaviors in the process of collective

\footnotetext{
${ }^{1} 29$ U.S.C. § 159(a)

${ }^{2}$ Clyde W. Summers, Exclusive Representation: A Comparative Inquire into a "unique" American Principle, 20 COMP. LAB. L. J. 47, 54 (1998).
}

bargaining. The National Labor Relations Act (NLRA) is the primary federal statute governing collective bargaining in the private sector. Under the NRLA, employees have the right to engage in organizing campaigns, form a union, collectively bargain with their employer, and take collective action. "Good faith" bargaining is required under the NLRA for both sides. Employers are required to bargain with the employees' representative in good faith with "wages, hours, and other terms and conditions of employment".

Unlike the other two examined countries, the United States utilizes the idea of exclusive representation. The NLRA explains that, once selected by a majority of employees in an appropriate bargaining unit, the union is the exclusive representative for all workers in that unit.

Section 9 (a) of the NLRA provides that,

Representatives designated or selected for the purposes of collective bargaining by the majority of the employees in a unit appropriate for such purposes, shall be the exclusive representatives of all the employees in such unit for the purposes of collective bargaining in respect to rates of pay, wages, hours of employment, and other conditions of employment. ${ }^{1}$

As for the employer, it is prohibited from bargaining on any mandatory subject of bargaining with any other unauthorized organization or with the employees individually. However, in China, the certain group of workers shall be a representative in the negotiation if there is no grassroots trade union. The employer can refuse to bargain with the union until the union gets majority support in an NLRB election or bargaining order. In practice, "no union" is one of the choices of the ballot. ${ }^{2}$ However, once the union establishes majority support through a Board election or bargaining order, the employer is obligated to bargain in good faith with the union on all mandatory subjects of bargaining. ${ }^{3}$ This system of exclusive representation is unique because it was designated by majority support in a bargaining unit. While in Germany, the election is based on a proportional representation that is more accurately manifesting employees' choice than the election by a majority. ${ }^{4}$

As for the exclusive representative, it must obtain majority support and it represents all employees in the bargaining unit regardless of union membership or the employees' desire to be represented. That is to say, if a representative does not meet majority support, it cannot represent any of the employees in the unit. In International Ladies' Garment

\footnotetext{
${ }^{3} 29$ U.S.C. $\S 158$ (a)(5) and $\S 158$ (d).

${ }^{4}$ Manfred Weiss and Marlene Schmidt. Labour Law and Industrial Relations in Germany. 4th rev. ed. Kluwer Law International, at 164-66 (2008).
} 
Workers Union v. NLRB (Bernard-Altman) ${ }^{5}$ case, the Supreme Court held that it was an unfair labor practice on both the employer and the union because the employer unlawfully recognized an exclusive bargaining representative before it had obtained majority supports, and the union unlawfully accepted the recognition.

The traditional exclusive bargaining representative is authorized to negotiate a collective bargaining agreement on all employees in a bargaining unit, but if a union has only minority support, there is no obligation to bargain with the union and the union can only negotiate "members only" contracts on behalf of its members. ${ }^{6}$ If there is a minority support, the minority union can provide their members some benefits, such as engaging in concerted collective activities and a guideline of protections under the NLRA. ${ }^{7}$

\section{GERMANY}

The Germany industrial relation system is based on the "dual system of interest representation." Collective labor disputes can be settled in one of two ways. First, the disputes can be settled by trade unions and the employer organizations or employers through collective agreements at a sector-level or a company level. Second, the disputes can be settled by workers' representation institutions and employers through works agreements at the establishment level. The collective bargaining is governed by the Collective Agreement Act (Tarifvertragsgesetz) of 1949. The Act indicates that the trade union and the employer (either employer organizations or individual employers) have rights to conclude a collective bargaining agreement. The dominant bargaining model is multi-employer bargaining model at the sector level between a trade union and employer organizations.

After World War II, Germany adopted a constitutional strict separation that required collective bargaining to take place without the State directly exerting influence. ${ }^{8}$ Then, after 2003, Laws for Reform of the Job Market (the Hartz reforms) were enacted to create employment opportunities, set additional wage subsidies, reform the Federal Employment Agency, and reduce unemployment

\footnotetext{
${ }^{5}$ Ilgwu v. NLRB, 366 U.S. 731, 732-40 (1961); International Ladies' Garment Workers Union v. NLRB, 463 F.2d 907 (1972); See more Majestic Weaving Co., 147 NLRB 859 (1964).

${ }^{6}$ Moshe Z. Marvit and Leigh Anne Schriever, Members-Only Unions: Can They Help Revitalize Workplace Democracy? The Century Foundation (Dec. 9, 2018), https://tcf.org/assets/downloads/Marvit_Schriever_Members -only_Unions.pdf.

${ }^{7}$ Clyde W. Summers, Exclusive Representation: A Comparative Inquire into a "unique" American Principle, 20 Cомp. Laв. L. J. 47, 64 (1998).

${ }^{8}$ Freyssinet, Jacques. Tripartite responses to the economic crisis in the principal Western European countries. ILO, at 25-27, 2010.

9 The Hartz reforms in Germany, BCG Foundation, https:/ / www.centreforpublicimpact.org/case-study/hartzreform/ (last visited Sep. 21, 2020).
}

benefits. ${ }^{9}$ Together with these reforms, the continuous decentralization of collective bargaining occurred as a result of the coverage of sector collective bargaining agreements moderately dropping while the coverage of company-level collective bargaining agreements and works agreements have increased.

The workers' representation by a works council is the basic set-up based on the Works Constitution Act (Betriebsverfassungsgesetz, BetrVG), which was amended in 2001. A Works Council can be voted on by all employees regardless of whether or not they are union members, and the works council can be created in all establishments where there are more than five employees. Additionally, another type of the works councils, called workers' representation of supervisory boards, occurs in the companies that employ more than 2,000 employees on a regular basis according to the Co-Determination Act of 1976. The role of a work council includes co-determination, information and consultation. However, the work council does not have a right to bargain with issues in the context of a collective bargaining agreement, unless the collective agreement explicitly allows it. ${ }^{10}$ Also, the work council has no right to strike. ${ }^{11} \mathrm{~A}$ works agreement (Betriebsvereinbarungen) is created by the employer and the works council, and it covers only employees in an establishment. Such agreements regulate all matters in an establishment, such as internal company rules, but the agreements cannot include the context of bargaining issues unless the collective agreement allowed it to do so.

Besides the works agreements, there are two types of collective agreements: a collective agreement (Tarifverträge) between a trade union and an employer association and a collective agreement (Volkswagen) between a trade union and an individual employer. ${ }^{12}$ The collective agreement has priority over an individual employment agreement unless the collective agreement allows deviations from a specific context or unless the implementation of the employment agreement is more favorable for employees. According to Section 77(3) of the Works Council Constitution Act, the principle of favorability ${ }^{13}$ does not apply to the cases of the relationship

10 Germany: Industrial relations profile, at 8, http://www.bollettinoadapt.it/old/files/document/6494EIRO_ GERMANY_201.pdf.

${ }^{11} I d$.

${ }^{12}$ XIVth Meeting of European Labour Court Judges (Paris, France), September 4, 2006, Germany Collective agreements, ILO, https://www.ilo.org/ifpdial/events/meetings/WCMS_159922 /lang--en/index.htm.

13 "Pursuant to Sec. 4(1) CA Act, a CBA takes precedence over an employment contract. Hence, collective bargaining rules are directly binding and mandatory for companies participating in the collective-bargaining system. The rules have priority over the stipulations of the employment contract, unless the CBA allows deviations in the specific context or unless the stipulations of the employment contract would be more favourable for the employee than the rules of the CBA (Sec. 4(3) CA Act, "favourability 
between collective contracts and works agreements because the collective contract cannot be a subject matter of a works agreement. However, if the collective agreement has an opening clause that allows the works agreement to amend or modify working conditions related to the clauses within the works agreement, the principle of favorability applies to such case. ${ }^{14}$

The implement of Hartz reform IV has indirectly and continuously enhanced the decline in collective bargaining coverage. ${ }^{15}$ Moreover, the number of union membership has declined but employer organizations have enhanced their power with opt-out clauses. ${ }^{16}$ Due to the preference to flexibility for collective agreements, the social partners have agreed to allow an opening clause in a collective agreement to deviate from the collective standards of sector level to company level. ${ }^{17}$ In 2008 crisis, Germany has mitigated the trend of decentralization and fragmentation, more regulatory changes were taken as responses. Legal reforms strengthened collective bargaining autonomy by the extension of collective agreements and the statutory minimum wage. ${ }^{18}$

The extension of collective agreement was rarely used in Germany because the extension made impacts on mitigating wage inequality but it also reduced employment. ${ }^{19}$ Collective agreements can be extended in terms of the Collective Agreements Act. Under the Collective Agreements Act, the federal and/or the regional labor ministers may extend an agreement if social partners' bipartite wage committee approved the extension and if the agreement covered at least $50 \%$ of employees in a

principle".)" See Fabian Seus, Company acquisition and labour law in Germany, VDMA.org, https://www.vdma.org/article//articleview/6126547.

14 BETRIEBSVEREINBARUNG WORKS AGREEMENT, Eurofound,

https:/ /www.eurofound.europa.eu/efemiredictionary/worksagreement-0 (last visited Dec.9, 2018).

${ }^{15}$ For example, in 2013, 30\% of the establishments in western Germany, and only $17 \%$ of the establishments in eastern Germany were covered by a sectoral collective bargaining agreement. See more Germany: Continued decline in collective bargaining and works council coverage, https:/ /www.eurofound.europa.eu/publications/article/2015/ germany-continued-decline-in-collective-bargaining-and-workscouncil-coverage (last visited Sep.21, 2020).

16 Kraemer, Birgit, Germany: Continued Decline in Collective Bargaining and Works Council Coverage, Eurofound, https:/ / www.eurofound.europa.eu/publications/article/2015/ germany-continued-decline-in-collective-bargaining-and-workscouncil-coverage (last visited Dec.9, 2018).

${ }^{17}$ Vogel, Sandra, Use of Opening Clauses in Collective Agreements, Eurofound,

https:/ / www.eurofound.europa.eu/publications/article/2006/ use-of-opening-clauses-in-collective-agreements (last visited Dec. 9, 2018).

${ }^{18}$ Voss, Eckhard, Katharina Schöneberg, and Ricardo Rodriguez Contreras. Collective bargaining in Europe in the 21st century. Publications Office of the European Union, at 45, 2015. sector. ${ }^{20}$ The extensions of collective agreements are rarely used; thus, the Germany collective bargaining coverage has dropped even lower than other widespread used EU member countries over the 2000s. ${ }^{21}$ The prerequisite for an extension has changed; nowadays the extension is of public interest.

For example, the Posted Workers Act aimed at setting minimum standards for working conditions in certain sectors, such as construction industry, cleaning services, letter delivery services, etc. ${ }^{22}$ Under the Posted Workers Act, the federal labor minister may extend an agreement at the sector-level to national-level if the extension is of public interest. ${ }^{23}$ That is to say, under this law, an extension of sectoral collective agreement can be extended to any industry rather than specific industries if the extension is served as public interest. ${ }^{24}$ In 2014, the Act to Strengthen the Autonomy of Collective Bargaining (Tarifautonomiestärkungsgesetz) was enforced to promote collective bargaining, to encourage the state in wage set, and to require to set the minimum wage starting on January 2015. If wages have been set by sector-level collective agreements that are less than the minimum wage, the wage will be valid until January $2017 .{ }^{25}$

\section{Tripartite Bargaining}

As a result of the Great Recession of 2008, western European countries had suffered Gross domestic product (GDP) declines and significant impacts on the realm of labor market. The combination of the financial crisis, company closures and increasing unemployment rate, restructuring, and the

${ }^{19}$ Oesingmann, Katrin (2016): Extension of Collective Agreements in Europe, CESifo DICE Report, ISSN 1613-6373, ifo Institut Leibniz-Institut für Wirtschaftsforschung an der Universitat München, München, Vol. 14, Iss. 2, pp. 59-64, at 64.

${ }^{20} \mathrm{Id}$. at 60.

${ }^{21}$ Germany: New law promotes collective bargaining, Eurofound, https://www.eurofound.europa.eu/publications/article/2015/ germany-new-law-promotes-collective-bargaining (last visited Sep. 21, 2020); Oesingmann, Katrin (2016): Extension of Collective Agreements in Europe, CESifo DICE Report, ISSN 1613-6373, ifo Institut - Leibniz-Institut für Wirtschaftsforschung an der Universitat München, München, Vol. 14, Iss. 2, pp. 59-64, at 61.

${ }^{22}$ The Posted Workers Directive 96/71/EC.

${ }^{23}$ See supra note 19.

${ }^{24}$ Translated by Jill Lindsay, Act to Strengthen the Autonomy of Collective Bargaining (Tarifautonomiestärkungsgesetz) of 11 August 2014, ILO, http://www.ilo.org/legacy/english/inwork/cbpolicy-

guide/germanacttostrengthentheautonomyofcollectivebargainin g2014.pdf.

25 Collective Bargaining, worker-participantion.eu, https://www.worker-participation.eu/National-Industrial-

Relations/Countries/Germany/Collective-Bargaining (last visited Dec.9, 2018). 
economy shifted from manufacturing toward services explained the declined coverage of collective agreements. ${ }^{26}$ In order to respond to the trend, various tripartite bargaining happened at the national inter-sector level, the sector level, the regional level, and mostly at the company level. ${ }^{27}$ Tripartite bargaining models involved governments, employers/employers' organization, and trade unions. Sometimes, the role of government is as a partner directly involved in reaching agreements, or more frequently, the role is making public policies that indirectly involve and influence the context of agreements. ${ }^{28}$ For example, the national government was aimed to make public policies on short-term working projects, unemployment benefits, labor market schemes, legislation, and much more during the crisis. ${ }^{29}$ There are three models of tripartite bargaining: institutionalized tripartism, flexible combination of bipartism and tripartism, and pragmatic and occasional tripartism. ${ }^{30}$ Namely, the institutionalized tripartism existed in some west European countries, such as Belgium, the Netherlands, and Ireland. There they have permanent tripartite institutions that provide a framework for consultation and agreements, and they also provide guidelines and regulations for collective bargaining. ${ }^{31}$ The flexible combination of bipartism and tripartism existed in other countries, such as France and Spain. There they have a two-stage system to reach collective agreements: first, the negotiation of inter-sectoral collective agreements; second, the dialogue with the government authorities confirmed by a signature joint document. ${ }^{32}$

Different than the first and second model, the last model pragmatic and occasional tripartism - was in other countries, such as Germany and the United Kingdom. They have neither set up official tripartite dialogue bodies nor adopted explicit tripartite agreements. ${ }^{33}$ As for Germany, tripartite dialogue has been tried several times during the crisis, but failed in the end.$^{34}$ Instead of utilizing tripartite dialogues or formal tripartite agreements, the flexible use of collective bargaining and comprehensive labor market reforms were applied to reach collective agreements or state-sponsored collective agreements. ${ }^{35}$ In

\footnotetext{
${ }^{26}$ See supra note 18 , at 42 .

${ }^{27}$ Glassner, Vera, and Maarten Keune. "Negotiating the crisis? Collective bargaining in Europe during the economic downturn." Dialogue working paper 10, at 20, (2010).

${ }^{28}$ See Id. Glassner, Vera, and Maarten Keune, at 19-20.

${ }^{29}$ See supra note 27 , at 6-7.

${ }^{30}$ Freyssinet, Jacques. Tripartite responses to the economic crisis in the principal Western European countries. ILO, at 7-31 (2010).

${ }^{31}$ Id.

${ }^{32} \mathrm{Id}$.

${ }^{33} \mathrm{Id}$.

${ }^{34} I d$. at $25-27$

${ }^{35}$ Lesch, Hagen, Sandra Vogel, and Paula Hellmich. The State and social partners working together: Germany's response to the global financial and economic crisis. No. 994961593002676. International Labour Organization, 2017.

${ }^{36}$ See supra note 27 , at $11-13$.
}

late 2008, the employers' association Gesamtmetal and IG Metall (Baden-Württemberg) reached a sector agreement on a step-wise increase of wages and lump-sum payment without pay increase as compensation. ${ }^{36}$

The apprenticeship pact (Ausbildungspakt) was concluded between the employers and the government in 2004 and renewed in 2007; however, the pact was hard to be followed by the employers to reach an agreement in 2009. ${ }^{37}$ Therefore, the partial unemployment/short-time working (Kurzarbeit) was created. The Kurzarbeit, as a statutory short-time working scheme, is a significant example of informal tripartism that supports temporary economic difficulty companies on reducing working hours and wages. ${ }^{38}$ The union membership has been declining, especially after the early 2004, because the Pforzheim Accord established a permission that allowed companies and workers to make special agreements at the company or plant level. ${ }^{39}$ Yet, the number of jobs during the crisis declined even more than the union membership; therefore, the union representative was broadly used in larger sized manufacture companies. "Tripartite" agreements can be made at the sector level; for example, the employers' organization Gesamtmetall and trade union IG Metall reached a sectoral agreement on the implementation of short-time working in metal companies. Additionally, government subsidies were paid to the employers to keep extended short-time working attractive. ${ }^{41}$ But mostly, the tripartite agreement was made at company level; for example, in order to get government funds to save the business, Schaeffler sought "crisis cooperation" with metalworkers' union IG Metall. ${ }^{42}$ Finally, they made a company-level agreement on job security ${ }^{43}$ concluded by the Workers' representation supervisory boards (Aufsichtsräte) with the right of co-determination. In other cases, the agreement can be concluded by the Works Council. ${ }^{44}$ Also, in other cases, the opening clauses within collective agreements were used to give the works council the right to reach the new agreements to cut costs and improve companies' competitiveness. ${ }^{45}$

\footnotetext{
${ }^{37}$ See supra note 30 , at 26.

${ }^{38}$ See supra note 27 , at 7 .

${ }^{39}$ Funk, Lothar. "Germany's Economic Renaissance: Lessons for the United States." (2015): 206-207.

40 Bispinck, Reinhard, and Heiner Dribbusch. "Collective bargaining, decentralisation and crisis management in the German metalworking industries since 1990." (2011): 67, at 55.

${ }^{41} \mathrm{Id}$. at 51.

${ }^{42} \mathrm{Id}$. at 52.

${ }^{43}$ See supra note 27 , at 18 .

${ }^{44}$ New Agreement on Job Security at Schaeffler Group, Eurofound, https://www.eurofound.europa.eu/publications/article/2009/ new-agreement-on-job-security-at-schaeffler-group (last visited Dec. 9, 2018); Freyssinet, Jacques. Tripartite responses to the economic crisis in the principal Western European countries. ILO, at 726, 2010.

${ }^{45}$ See supra note 40 , at 57 .
} 
At the end of 2014, a new alliance for vocational and further training was announced by the German Confederation of Trade Unions (DGB) which ended the Pact on Apprenticeship. The new alliance is aimed at stimulating the number of apprenticeship positions, enhancing advanced training system, and encouraging young people to take up apprenticeships. ${ }^{46}$

The Minimum Wage Act (Mindestlohngesetz, MiLoG) was enacted in 2015 . The minimum wage rate was finally set by the government considering non-binding recommendations from the expert committee and a mechanism (i.e. indexation); however, social partners were not directly involved in determining the national minimum wage. ${ }^{47}$ The expert committee aimed to reach consensus on the level of the minimum wage, and then provided recommendations to the government. ${ }^{48}$ The people in an expert committee should represent the general interests of the country and should have full consultation with the related social partners. ${ }^{49}$ The selfemployed and low-wage foreign workers were widespread because of the globalization and the mobility of the labor market. As a result of increased foreign workers, wage dumping (Lohndumping), as well as social dumping, created a negative influence on native labor standards determined for the collective agreements.

In response to this trend, in 2018, the specific rates ${ }^{50}$ of national minimum wage were abolished. However, there is one exception - seasonal workers and foreign workers in the seasonal contracts. These workers may deduct board and lodging costs from the minimum wage.$^{51}$ On the other hand, if the minimum wage of the collective agreement is less than the statutory minimum wage, the statutory minimum wage will apply. ${ }^{52}$ Apart from the minimum wage-setting, the government never made any institutional changes in the wage-setting process. The wage-setting process is based on collective negotiation without direct influence of the government, which is guaranteed by the Germany Constitution. ${ }^{53}$

\footnotetext{
${ }^{46}$ Germany: New Alliance for Vocational Training and Further Employment, Eurofound, https:/ / www.eurofound.europa.eu/publications/article/2015/ germany-new-alliance-for-vocational-training-and-furtheremployment (last visited Dec.9, 2018).

${ }^{47}$ Karel Fric, Industrial relations: Statutory minimum wages 2018, Eurofound, http:/ / www.astridonline.it/static/upload/euro/eurofund_min-wages-report2018.pdf, at 12.

${ }^{48}$ RESEARCH REPORT: Industrial relations statutory minimum wages 2018, Eurofound, http://www.astridonline.it/static/upload/euro/eurofund_min-wages-report2018.pdf, at 12-15.

49 Minimum Policy Guide, ILO, http:/ /www.ilo.org/wcmsp5/groups/public/---ed_protect/--protrav/--travail/documents/genericdocument/wcms_508528.pdf, at7.
}

\section{National Pattern Bargaining}

National pattern bargaining rarely exists in Germany. In the private sector, an extension of a collective agreement may be issued in terms of public interest, but the employment in the area cannot fall below the generally prevailing level. In addition, the extension is only issued if at least one party makes an application and if the extension involves the employers on whom the collective bargaining agreement is already binding at least $50 \%$ of all employees within its occupational scope of application. Moreover, the government is not authorized to change any content of the agreement, and the government cannot go against the will of both parties. ${ }^{54}$ As a result of union wage premiums, employers hired non-union members that they can pay below collective bargaining wages during the economic crisis during the Weimar era. Therefore, Section 5 of the 1949 Collective Agreements Act (TVG) states that there is a possibility to extend a sector-level collective bargaining contract to non-organized social partners within the region and industry covered by the corresponding collective agreement. The imposing extension order is issued by the Federal or Land Minister of Labor and Social Affairs upon the application from either or both parties, and the order requires consent from a committee with three representatives respectively from the umbrella associations of both sides. ${ }^{55}$

The Posting Workers Act (1996) allows the federal labor minister to extend a sector collective bargaining agreement to a national level in terms of social partners' pleas, and the sector collective bargaining agreement can be extended if the sectoral agreement has covered more than half of the employees and it is for the public interest. ${ }^{56}$ The extension of a collective bargaining can also be issued by government decree since the year of 1999, which does not to request the consent from a committee of representatives. This is allowed because the committee's consent is hard to achieve in the construction sector regarding the applicability of minimum wage to posted workers. ${ }^{57}$

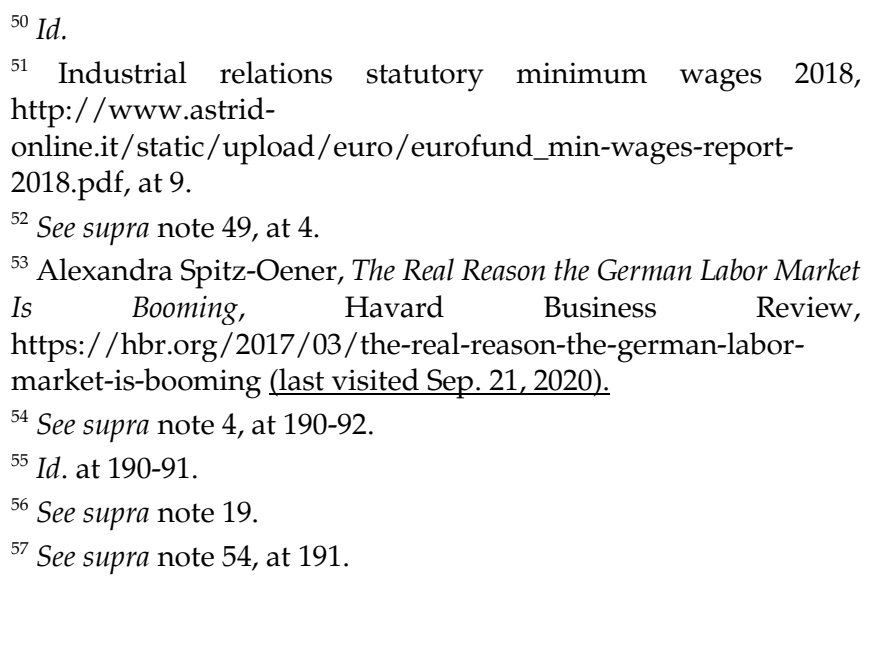




\section{The Enforcement of Collective Agreements CHINA}

The enforcement of collective agreements is based on the state policy under state-control: the ACFTU Work Plan on Deepening Collective Bargaining (2014-2018). ${ }^{58}$ The Plan states that collective agreements are to be enforced through three methods: 1) the local trade unions' monitoring and inspection; 2) employee representatives supervise the enforcement of collective agreements with the assistant of local trade unions; and 3) cooperation with labor administrative departments to inspect the enforcement of collective agreements. ${ }^{59}$ However, these three methods are hard to efficiently implement to enforce the collective agreements in practice. For instance, labor unrest has broken out even though the plant covered by the collective contract.

Moreover, there are no "peace clauses" (no-strike clauses) in the collective agreements, which indicates social parties participated passively in the first-time government-lead negotiation. Employers were unwilling to negotiate with their employees in a good faith bargain. Also, instead of "arbitration clauses", China's collective agreements have a simple article on dispute resolution following labor laws. In this article, if there is a labor dispute, labor arbitration is statutory and mandatory after negotiation was failed or a deadlock occurred. While, in the United States, an arbitration clause is generally one of the standard clauses in the context of collective agreement to clarify the resolution of disputes concerning the application and interpretation of the collective agreement if these disputes are not resolved through the grievance process. Different from the United States labor arbitration system, the Chinese labor arbitration is deemed to be semi-judicial process which is normally mandatory and statutory procedure that must be undertaken before a dispute on the collective agreements' application and interpretation can be taken to court. And the grassroots trade union is the workers' representative in labor arbitration and litigation. Individual workers can sue in the labor arbitration and court in term of an individual labor contract or employment relationship.

Further, the enforcement of an arbitration award has not yet been affirmed by the court even though the award is legitimate. Labor laws give individual employees rather than employers more rooms to sue in courts, especially in

58 Zhonghua Quanguo Zongguohui Shenhua Jiti Xieshang Gongzuo Guihua (2014-2018) (中华全国总工会关于印发《中华全 国总工会深化集体协商工作规划(2014-2018年)》的通知) [Notice of the All-China Federation of Trade Unions on Distributing the Plan for the All-China Federation of Trade Unions to Deepen the Work of Collective Negotiation (2014-2018)], 总工发[2014] 11号[ ACFTU [2014] No. 11].

${ }^{59} \mathrm{Id}$. final arbitration award cases, but the employer always can find a way to sue in the court even though the arbitration award is final and binding. The "final and binding" arbitration award means that the employer cannot sue in court unless allowed under certain situation according to the Labor Arbitration Law, while employees can sue in a court if they do not satisfy the awards. A Guangdong report showed that less than $8 \%$ final arbitration cases was binding, and above $70 \%$ arbitration awards were brought to the court for a judicial decision.

The report shows that the arbitration awards sued in the first-stance court have reached $52 \%$ after the arbitration awards in the past three years. ${ }^{60}$ From 2014 to 2016, the awards sued in the court were $51.6 \%, 27.1 \%$, and $26.0 \%$ respectively. ${ }^{61}$ Moreover, once labor disputes entered the courts, there is a possibility that such case will continuously go to the higher court after the first-instance trail. For example, about $30 \%$ of first-instance court decisions are appealed to the higher court in Guangzhou through 2011 to 2013 . $^{62}$

\section{UNITED STATES}

\section{Use and Deference to Arbitration}

Section 203 (d) of the Labor Management Relations Act of 1947 declares that

Final adjustment by a method agreed upon by the parties is declared to be the desirable method for settlement of grievance disputes arising over the application or interpretation of an existing collective-bargaining agreement. The Service is directed to make its conciliation and mediation services available in the settlement of such grievance disputes only as a last resort and in exceptional cases. ${ }^{63}$

Section 301 (a) of the Labor Management Relations Act of 1947 says that

Suits for violation of contracts between an employer and a labor organization representing employees in an industry affecting commerce as defined in this Act, or between any such labor organization, may be brought in any district court of the United States having jurisdiction of the parties, without respect to the amount in controversy or without regard to the citizenship of the parties. ${ }^{64}$

${ }^{60}$ Guangzhou White Paper on Labor Disputes (2011-2013) (广州 劳动争议诉讼情况白皮书, 2011-2013), Guangzhou Court Net (广 州审判网).

${ }^{61}$ Guangzhou White Paper on Labor Disputes (2014-2016) (广州 劳动争议诉讼情况白皮书, 2014-2016), Guangzhou Court Net (广 州审判网).

${ }^{62}$ See supra note 60.

${ }^{63} 29$ U.S. Code $\S 173$ (d).

${ }^{64} 29$ U.S. Code $\S 185$ (a) and (b). 
The Supreme Court explained Section 301(a) in the Textile Workers v. Lincoln Mills (1957) case, which ended the confusion and uncertainty of Section 301(a). The Supreme Court held that the collective bargaining agreement with an arbitration clause was specifically enforceable. Also, Congress was eager to promote collective bargaining agreements that ended with an arbitration clause and a no strike clause in order to encourage industrial peace. ${ }^{65}$

In 1960, the deference to labor arbitration was affirmed by the Supreme Court in the famous "Steelworkers Trilogy" cases. The Supreme Court upheld that: 1) labor arbitration should be ordered when the parties agreed to submit all grievances to the arbitration, and the courts actually have no business considering the merits of the grievance; ${ }^{66} 2$ ) labor arbitration clauses should be explained in a broad way, and the arbitration should be ordered unless there is a positive assurance of non-intention to arbitrate on the asserted dispute, ${ }^{67}$ and 3) the enforcement of an arbitration award should be affirmed by the court if the arbitrator's award is legitimate only as it "draws its essence" from the collective bargaining contract. ${ }^{68}$ These three cases confirmed the significant role of labor arbitration as a preferred resolution. As a result, arbitration cases have increasingly been used to resolve labor-management disputes.

Further, there are four significant cases that support the enforceability of a mandatory arbitration clause with a waiver in individual employment contracts. First, in the Gardner-Denver case, the Supreme Court held that an employee's statutory right to sue in court under Title VII of the Civil Rights Act of 1964 is not prevented by the prior submission to final arbitration under the collective bargaining agreement with a nondiscrimination clause. ${ }^{69}$ The Gardner-Denver case indicated the issue of discrimination was addressed in the collective bargaining agreement, and the arbitration based on the collective bargaining contract cannot preclude an individual's right to pursue the judicial resolution of his statutory claim. However, the Gilmer case was about the enforcement of an individual employment agreement to arbitrate statutory claims under the FAA. ${ }^{70}$ In the Gilmer case (1991), the Supreme Court indicated that Gilmer should resolve his ADEA claim following the arbitration clause unless he can show the conflict between arbitration and ADEA's purposes.

\footnotetext{
${ }^{65}$ Textile Workers v. Lincoln Mills, 353 U.S. 448, 450-54 (1957).

${ }^{66}$ United Steelworkers of America v. American Manufacturing. Co., 363 U.S. 564, 564-69 (1960).

${ }^{67}$ United Steelworkers of America v. Warrior \& Gulf Navigation Co., 363 U.S. 574, 582-83 (1960).

${ }^{68}$ United Steelworkers of America v. Enterprise Wheel \& Car Corp., 363 U.S. 593, 598 (1960).

${ }^{69}$ Alexander v. Gardner-Denver Co., 415 U.S. 36, 44-60 (1947).

${ }^{70}$ Gilmer v. Interstate/Johnson Lane Corp., 500 U.S. 20, 33-35 (1991).
}

Second, in Wright v. Universal Maritime Service Corp. (1998), the Supreme Court held that the collective bargaining agreement with a general arbitration clause cannot demand Wright to use the arbitration procedure without a clear and unmistakable waiver of employees' statutory rights to a federal forum. ${ }^{71}$ The Gilmer case is different than the Wright case because Gilmer involved a waiver of rights in the individual contract. The Wright case, however, did not have a waiver that matched the "clear and unmistakable standard," and the waiver prevented Wright from suing in the federal court. Also, Wright raised another unsolved question on whether or not the union representative can make a clearly and unmistakably unionnegotiated collective bargaining agreement to wave employees' rights to a judicial forum of employment discrimination claims. ${ }^{72}$ As a result, the mandatory arbitration with a class action waiver clause has increased since the year 1980 .

Third, in 14 Penn Plaza v. Pyett (2009) ${ }^{73}$, the U.S. Supreme Court held that unions may waive their members' rights to pursue antidiscrimination claims in court by agreeing to a mandatory arbitration clause. The holding rejected many of the rationales that had governed the Court in the Gardner-Denver case. Fourth, in Epic Systems Corp. v. Lewis (2018), the Supreme Court held that arbitration agreements providing for individual proceedings, and waiving class or collective actions, are lawful and enforceable. ${ }^{74}$ The court emphasized that Section 7 of the National Labor Relations Act (NLRA) (1953) only mentions the concerted activities to organize a union and bargain collectively, rather than rules on how to regulate adjudication of class or collective actions in court or arbitration. ${ }^{75}$

As distinct from labor arbitration, employment arbitration is a resolution of employment strife between an employer and individual employee, which normally is of less concern of the employment relationship. It is of less concern because an individual employee was discharged at that time or the employee resigned as a result of the employer created hostile working environment, and after that neither party wants to rebuild the relationship. ${ }^{76}$ As the paper mentioned before, the term arbitration has been used broadly because the courts have expanded the utility of arbitration. Moreover, not only in labor arbitration cases but in employment arbitration cases, the Courts have

\footnotetext{
${ }^{71}$ Wright v. Universal Mar. Serv. Corp., 525 U.S. 70, 75-82 (1998).

${ }^{72}$ Id. at 75-77.

${ }^{73} 14$ Penn Plaza LLC v. Pyett, 556 U.S. 247.

${ }^{74}$ Epic Sys. Corp. v. Lewis, 138 S. Ct. 1612 (584 U.S. __ (2018) 525); NLRB v. Murphy Oil USA (86 U.S.L.W.3111); Ernest \& Young v. Morris (86 U.S.L.W. 3111).

${ }^{75} \mathrm{Id}$.

76 Norm Brand, How to Choose an Employment Arbitrator, Mediate.com, https://www.mediate.com/articles/brandN4.cfm (last visited Sep. 21, 2020).
} 
supported mandatory arbitration. ${ }^{77}$ The Supreme Court has clearly established that an individual employment arbitration agreement with the class/collective actions waiver is lawful and enforceable. ${ }^{78}$

\section{The No Strike Clauses}

In the collective bargaining agreement, explicit no-strike clauses generally prohibit strikes during the life of the contract, and a no-strike clause may be implied when a contract contains a broad mandatory arbitration clause. The Supreme Court has held that a no-strike clause is the quid pro quo of a broad mandatory arbitration clause, and the injunction of strikes would be supported where the employees have the contractual right to arbitrate the dispute. $^{79}$

The Norris-LaGuardia Act of 1932 restricted the use of court injunction in labor disputes against strikes, picketing, and boycotts. Labor organizations have enhanced their strength and power since the year of 1935, the Congress's attitude towards labor disputes had changed from protecting labor movement to encouraging the collective bargaining and peaceful resolution of industrial disputes. ${ }^{80}$ In 1947, Congress enacted the Labor Management Relations Act (Taft-Hartley Act). Section 301(a) of the Labor Management Relations Act has authorized that federal courts have jurisdiction where a breach of contract has happened between an employer and a union organization. A breach of contract gives the district courts of the United States jurisdiction of parties without considering the parties' citizenship or the amount in controversy. ${ }^{81}$

In Boys Markets, ${ }^{82}$ the Supreme Court held that there are three tests for an anti-strike injunction. The first one is the "over an arbitrable grievance" test, which indicates the strike must be over a broad mandatory arbitration clause implying a no-strike obligation that both parties contractually bound to arbitrate. Second, either the employer or the union must be ordered to arbitrate. Third, the moving party must satisfy traditional equity requirements in requiring the injunction. ${ }^{83}$ The Boys

\footnotetext{
${ }^{77}$ AT\&T Mobility LLC v. Concepcion, 563 U.S. 333 (2011); Am. Express Co. v. Italian Colors Rest, 570 U.S. 228 (2013).

${ }^{78}$ See supra note 74 .

${ }^{79}$ Local 174, Teamsters, Chauffeurs, Warehousemen \& Helpers of Am. v. Lucas Flour Co., 369 U.S. 95 (1962); Gateway Coal Co. v. United Mine Workers, 414 U.S. 368 (1974).

${ }^{80}$ Boys Markets, Inc. v. Retail Clerks Local 770, 398 U.S. 235, 251 (1970).

${ }^{81} 29$ U.S.C. $\S 185$ (a).

${ }^{82}$ See supra note 80.

${ }^{83}$ Nolan, Dennis R., and Richard A. Bales. Labor and Employment Arbitration In a Nutshell. Third edition. St. Paul, MN: West Academic Publishing, at 124, 2017.

${ }^{84}$ Sinclair Refining Co. v. Atkinson, 370 U.S. 195 (1962); §4 of the Norris-LaGuardia Act of 1932 has prevented the federal courts
}

Markets case revived the decision of anti-injunction in the Sinclair case that federal courts precluded from issuing injunction against strike under a contract with no-strike clause. ${ }^{84}$ However, the Supreme Court limited that Boys Markets exception and refused to expand every strike in breach of a collective bargaining contract. In Buffalo Forge Co. v. United Steelworkers, the Supreme Court held that the district court was not empowered to enjoin the sympathy strike by issuing an injunction when the primary strike is not subject to the binding arbitration clause. ${ }^{85}$ Further, the Cedar Coal Co. v. UMW Local 1759 held that an injunction is appropriate when the object and potential effect of a sympathy strike is to compel the primary strikers' employer to concede an arbitrable issue. From the two important cases above we see that primary strikes may be enjoined if the underlying disputes are subject to a mandatory arbitration clause, but sympathy strikes may not be enjoined if the dispute underlying the primary strike is not subject to mandatory arbitration. However, a sympathy strike may be enjoined if it exerted pressure on the employer to concede an arbitrable issue, and if it prevented the employer from the contractually mandated arbitration procedure. ${ }^{86}$

\section{GERMANY}

Germany's Federal Labor Court (Bundesarbeitsgericht) holds that if there is a conflict among several collective agreements in an operation, the collective agreement created by the trade union with a majority support will apply in the operation. The Act on Collective Bargaining Unity (Tarifeinheitsgesetz) was enacted in 2015. The Act allows court proceedings to determine the majority union representation in an operation, which reestablishes the principle of Unitarian Bargaining (Tarifeinheit). ${ }^{87}$ As for minority unions, on the one hand, the Act does not prohibit small trade unions' right to strike. On the other hand, small trade unions' collective agreements may be rejected only if a collective agreement has adequately considered the minority union members' interests, which is determined by a trade union with majority support. ${ }^{88}$ Germany is

from issuing injunction against non-violent labor disputes, see more 29 U.S. Code $\S 104$.

${ }^{85}$ Buffalo Forge Co. v. United Steelworkers of America, 428 U.S. 397, 404-13 (1976).

${ }^{86}$ Thau, J. C. (1977). Labor Law-Injuctions-Court May Enjoin Sympathy Strike Where Purpose and Effect Is to Compel Concession of Arbitrable Issue. Cornell L. Rev., 63, 507, at 519-22.

${ }^{87}$ Clauwaert, Stefan, and Isabelle Schömann, "The Crisis and National Labour Law Reforms: A Mapping Exercise." European Labour Law Journal 3, no. 1 (2012): 54-69; Germany: Act on Collective Agreement Unity is compatible with the constitution, etui., https:/ / www.etui.org/ReformsWatch/Germany/GermanyAct-on-Collective-Agreement-Unity-is-compatible-with-theconstitution.

${ }^{88}$ Pascal Kremp LL.M., Act on Uniformity of Collective Agreements (Tarifeinheitsgesetz) in most parts compatible with the German Constitution (Grundgesetz, GG), DLA PIPER Employment 
different from the United States because there is no mandatory arbitration clause in the collective agreements. However, Germany is similar to the United States because Germany has a peace clause while the United States has a no-strike clause.

The peace clause can be extended after the termination of the contract to prevent industrial actions. Since Germany has the sector-level and establishment-level of collective bargaining, a big trade union is needed to create a sectorlevel collective agreement with employers' associations. ${ }^{89}$ Under those situations, the collective dispute resolution is not used to prevent strikes. However, since the creation of the sector-level collective agreements and the start of the company-level bargaining, the peace clause can be used to prevent strikes. ${ }^{90}$

Conclusively, a company-level bargaining model broadly uses in China and United States, while sector-level bargaining models is broadly used in Germany. Due to the nature of bargain model in the contemporary of China, collective negotiation is extremely fragment, while U.S. experience of fragment bargaining will provide implications for Chinese labor laws. And, both United States and Germany experience on the enforcement of collective contracts will give hints for China to efficient enforce an existing collective contract.

\section{Methods OF AvoIding STRIKES}

\section{CHINA}

The right of strike was deleted from the China Constitution of 1982, but had been included in the text of the Constitution in 1975 and 1978. Unlike industrial actions in the United States and Germany, industrial actions in China are organized by workers themselves with or without other non-governmental organizations' assistance. Article 27 of the Labor Union Law (2001) states that if there is a work stoppage, the relevant grassroots trade union has the duty to represent the employees to negotiate with their employer in order to resume production.

The right to strike is highly discussed. Regarding the right to strike, there are three main arguments. The first argument is that strikes are legal. The "Covenant on Economic, Social and Cultural Rights" approved by the Standing Committee of the National People's Congress demonstrates Chinese workers have "the right to strike". ${ }^{91}$

Germany

https:/ /blogs.dlapiper.com/employmentgermany/2017/07/17 /act-on-uniformity-of-collective-agreements-tarifeinheitsgesetzin-most-parts-compatible-with-the-german-constitutiongrundgesetz-gg/.

${ }^{89}$ See supra note 54 , at 198.

${ }^{90} \mathrm{Id}$. at 199.

91 Chang Kai, About the Legality of Strikes and Its Legal Regulations, Contemporary Law 2012, Issue 5, p. 112.
The second argument is that strikes are illegal, and laws do not tacitly allow workers to have the right to strike. The labor law stipulates that companies cannot force workers to work for them, and workers can refuse to work or quit the job as long as they wish. Therefore, based on the nature of rights in terms of labor laws, work stoppage is an individual right, not the right to collective action. ${ }^{92}$ However, this argument does not take into account that in countries where unions can organize strikes, strikes are the last resort in interests' dispute negotiation, and compared with workers-driven strikes, union organized strikes are more costly and difficult to disorder industrial peace. The third argument is that the strike is neither legal nor illegal. This argument holds that although the 1982 Constitution abolished the 1978 Constitution on freedom of strike, the law never prohibited strikes. And "prohibition of strikes" will not solve the labor unrest problem. Regarding the "Covenant on Economic, Social and Cultural Rights" approved by the Standing Committee of the National People's Congress, labor laws and constitution have not declared any reservations or made other special instructions. Because the laws have not explicitly authorized the right to strikes, but based on the international commitments, strikes cannot be considered illegal. Moreover, Article 27 of the "Trade Union Law" does not clearly stipulate the right to strike and slowdowns. Even though illegal acts that endanger public order or "hit or smash" sometimes occurred with strikes, these acts should be treated as individual and personal illegal acts rather than presuming the illegality of the strike. ${ }^{93}$

The worker-driven strikes, therefore, are not generally prohibited in laws. However, the right to organize strikes is not authorized to grassroots trade unions, so strikes that occur in China are wildcat strikes. Also, there is no regulation limiting the industrial actions, and there is no peace clause in the context of collective agreements in China. As for the central government, the governments generally allow industrial actions, but they did not welcome political stoppages.

\section{UNITED STATES}

The concept of "promoting industrial peace" can be understood as a method to prohibit costly strategic behavior as well as to promote cooperative relations between the labor and management. ${ }^{94}$ Inconsistent with the "robber baron," a "captain of industry" was a group of business leaders who focused on encouraging productivity

${ }^{92}$ Hou Lingling, Legal Regulation of Collective Dispute Actions of Workers from the Perspective of Comparative Law, Law Science 2013, Issue 4, pp. 110-111.

${ }^{93}$ Wang Quanxing and Ni Xiongfei, On the Relationship between my country's Strike Legislation and Strike Transition, Modern Law 2012, Issue 7, p. 188.

${ }^{94}$ Dau-Schmidt, K. G. (2000). Labor Law and Industrial Peace: A Comparative Analysis of the United States, the United Kingdom, Germany, and Japan under the Bargaining Model. Tul. J. Int'l $\mathcal{E}$ Comp. L., 8, 117, at 133-35. 
and committed into industrial peace by the constraints of collective bargaining. ${ }^{95}$ Congress has enacted various labor statutes to promote industrial peace. The NorrisLaGuardia Act of 1932 indicated federal courts cannot flatly issue an injunction against a series of labor actions. The National Labor Relations Act of 1935 (the Wagner Act) inclined to protect unionism and collective bargaining. Lastly, the Labor Management Relations Act of 1947 (the Taft-Hartley Act) shifted its purpose from protecting unionism to a more neutral position.

Moreover, the Supreme Court has set up various tests to enforce a collective bargaining agreement. As the paper mentioned above, for example, there are two tests to determine whether the court will issue an injunction against a strike or a sympathy strike: the "over an arbitrable grievance" test in Boys Markets case and the "object of the strike" test in Cedar Coal case. A grievance procedure in the collective bargaining agreement is fully enforced on both parties, and a no-strike clause is guaranteed the enforcement of collective contract.

Historically, the American working class enjoys individualism rather than collectivism based on the social context. ${ }^{96}$ On the other hand, American managers are reluctant to tolerate unionism and use strategies to avoid the organization of their employees. ${ }^{97}$ Additionally, government prosecution of radical unionism suppressed labor protests and affected the evolution of the American labor movement. ${ }^{98}$ Because the labor movement was more likely to succeed with modest demands concerning the conditions of employment rather than more radical political activities to change the capitalist system, the demands of the American labor movement have focused on "bread and butter" issues such as increasing wages and improving working conditions. ${ }^{99}$ The number of strikes was also affected by foreign trade and the declining prospects of American workers. The workers were afraid of having their work sent overseas. According to the figure below, ${ }^{100}$ the number of work stoppages had been dramatically decreased since the year 1982 because of the above methods and reasons together resulted in declining of work stoppages.

\footnotetext{
${ }^{95} I d$.

${ }^{96}$ Lipset, S. M. (1997). American exceptionalism: A double-edged sword. WW Norton \& Company.

${ }^{97}$ Dulles, Foster Rhea, and Melvyn Dubofsky. Labor In America: A History. 5th ed. Arlington Heights, Ill.: Harlan Davidson, 1993; See supra note 94 , at $133-34$.

${ }^{98}$ Forbath, William E., and William E. Forbath. Law and the shaping of the American labor movement. Harvard University Press, at 63, 2009.

${ }^{99}$ See supra note 94.

${ }^{100}$ News Release U.S. Department of Labor, MAJOR WORK STOPPAGES IN 2017 (BLS), https:/ / www.bls.gov/news.release/pdf/wkstp.pdf.

${ }^{101}$ BVerfG Acc. 14.11.1995, Ref: 1 BvR 601/92.
}

Work stoppages involving 1,000 or more workers, 1947-2017

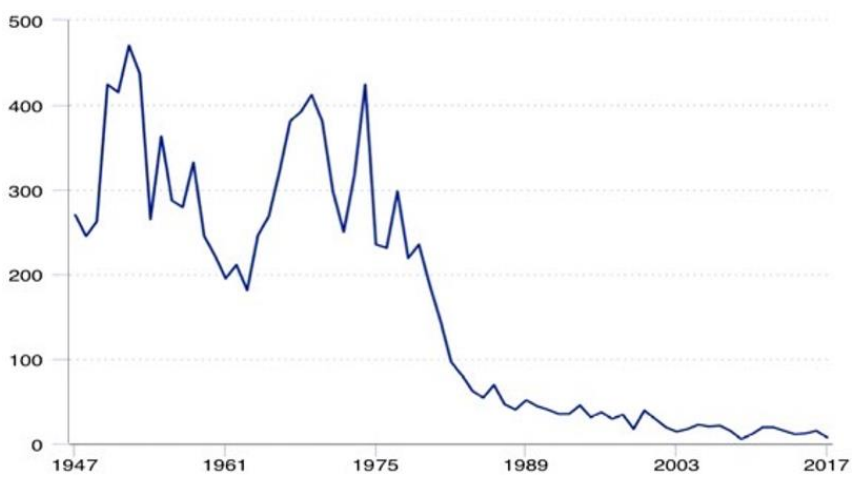

\section{GERMANY}

In Germany, Art. 9(3), of the Basic Law of the Federal Constitutional Court, gives workers the right to industrial actions. ${ }^{101}$ However, only trade unions with capacity to bargain collectively can call strikes, and the strike cannot be called if there is a peace clause in the collective agreement that is currently in effect or for a period afterwards. The Federal Labor Court applied the principle of proportionality to determine the use of industrial actions that will comply with the peace clause. For instance, a strike must be fair and the last resort. In addition, the strike must be preceded by a secret ballot of union members. ${ }^{102}$ Similar to the United States, wildcat strikes are illegal and forbidden. ${ }^{103}$ Sympathy strikes may be allowed under the trade unions' control in certain situations. ${ }^{104}$

Another type of industrial action is the flash mob. The Constitution Court held that a flash mob was not against the Constitution. ${ }^{105}$ During the negotiation process, the trade union can call a flash mob, or a token strike. ${ }^{106}$ The Federal Labor Court held that, for a trade union, the permissibility of a flash mob must be recognized as a dispute method. The Federal Labor Court also held that, for an employer, the sufficient reaction against a flash mob is temporary business closure under the right of domestic ownership. ${ }^{107}$ The labor disputes over business decisions have yet to be determined in the courts.

${ }^{102}$ See supra note 54, at 203.

${ }^{103}$ The Legality of Employee Strike Action, Employment Law Watch, https://www.employmentlawwatch.com/2015/07/articles/em ployment-us/the-legality-of-employee-strike-action/.

104 Germany: Industrial relations profile, at 2-3, available at http:/ / www.bollettinoadapt.it/old/files/document/6494EIRO_ GERMANY_201.pdf (last visited Sep. 21, 2020).

${ }^{105}$ BVerfG 26.3.2014 - 1 BvR 3185/09, NZA 2014 p. 493.

${ }^{106}$ For example, customers are asked to leave full shopping trolleys containing low-value goods behind in stores or purchase large numbers of low-value items in order to significantly slow down the payment process. See more BAG 22.9.2009 - 1 AZR 972/08, NZA 2009, 1347.

${ }^{107}$ Dirkzwager legal \& tax,_Methods of Industrial Action in Germany, Legal

Knowledge Portal, 
The court held that this is still an open question. Some courts held that strikes are legal because if there is a demand that will make an impact on a business decision, the legality of strikes remain unchallenged and the relocation of the enterprise would be just a consequence of a collective autonomy without triggering any legal consequence. ${ }^{108}$ However, in more cases, workers and their unions do not have enough capacity and power to take strike action to prevent the relocation or closure of enterprises.

Generally, the Federal Labor Court is more flexible with regard to industrial actions as compared to the United States court system. In Germany, the strike aimed to achieve settlement of a collective labor disputes, which must be linked to a collective contract and must be initiated by a trade union. ${ }^{109}$ The right to strike is prohibited in three ways. First, strikes must not infringe on other citizens' fundamental rights or damage the public interest. ${ }^{110}$ Second, if there is a peace obligation explicitly or implicitly in the context of a collective agreement, both parties are required to follow the obligation related to the subject matters of the collective agreement. ${ }^{111}$ After the termination of a collective agreement, there is no longer a peace obligation, unless the parties agree on a continuing peace obligation to have more time for negotiations without the threat of a strike. ${ }^{12}$ Third, a strike should be used after all other methods have failed; a strike should be used as the last resort. A strike should respect the principle of proportionality. ${ }^{113} \mathrm{~A}$ trade union, instead of the court, should decide whether all other means failed before a strike was called. ${ }^{114}$

https:/ / legalknowledgeportal.com/2017/05/02/methods-ofindustrial-action-in-germany/ (last visited Dec. 9, 2018).

${ }^{108}$ Däubler, Wolfgang. "Industrial Actions in Germany-Realistic in an International Context?.", at 49-50 (2015).

109 Warmeck, W. "Strike rules in the EU27 and beyond." $A$ comparative overview. Brusel: European Trade Union Institute for Research, Education and Health and Safety (ETUIREHS) (2007).

${ }^{110}$ Waas, Bernd. "Strike as a fundamental right of the workers and its risks of conflicting with other fundamental rights of the citizens." In XX World Congress, Santiago de Chile, pp. 1-88, at 4445, 2012.

111 See supra note 108 , at 45 .

112 See supra note 110 , at 40 .

113 "Proportionality is a legal principle that allows (or requires) balancing between competing values. This enables judges to decide whether a measure has gone beyond what is required to attain a legitimate goal and whether its claimed benefits exceed the costs", see more Melanie Smith, Benedikt Pirker, Proportionality Analysis and Models of Judicial Review, 51 Common Market L. Rev. 1292, 1293 (2014)

${ }^{114}$ See supra note 108.

${ }^{115}$ Co-determination Act in the Coal, Iron \& Steel Industry (1951); Supplementary Co-determination Act (1956); Co-determination Act (1976): The Codetermination Act of 1976 indicated the corporate governance mechanism in Germany. See more Page,
Other than limiting the right to strike, codetermination is another way to avoid industrial actions. There are two levels of the right to codetermination: 1) codetermination through the works council (Betriebsrat) at the establishment level and 2) codetermination through the supervisory board (Aufsichtsrat) at the company and group level. As for the works council, the right of codetermination is regulated by the Works Constitution Act (1972). As for the supervisory board, the right of codetermination is regulated by the Co-Determination Acts ${ }^{115}$ and Third Part Act of 2004 (former Works Constitution Act (1952)). ${ }^{116}$

The system of the works council resolved many labor disputes without inducing industrial actions. The system also guaranteed workers' participation in the regulation of working conditions, and the system guaranteed workers input into management prerogatives. ${ }^{117}$ The works councilors are selected from employees in a workplace. All employees, including part-time workers and interns, who are older than eighteen and have served at least six months, have the right to vote on the works councilors. ${ }^{118}$ The employees who are allowed to vote do not include managerial employees and independent contractors. ${ }^{119}$ If the employees were sent to another employer until the end of some work, those employees are eligible to vote if they are working more than three months in the firm. ${ }^{120}$ If an employer interferes with the establishment of the works council, the employer can be subject to criminal fines or the maximum of one year imprisonment. ${ }^{121}$

Work council members can be selected if there are more than five employees in an establishment; ${ }^{122}$ in large

Rebecca. Co-determination in Germany-a beginners' guide. 5. No. 33. Arbeitspapier, at 12, 2011.

${ }^{116}$ Page, Rebecca. Co-determination in Germany-a beginners' guide. 5. No. 33. Arbeitspapier, at 12, 2011.

${ }^{117}$ In businesses with more than 100 permanent employees, the Works Council must establish an economic committee (Wirtschaftsausschuss). The economic committee discusses economic matters with management and then reports those consultations to the Works Council, see also Worldwide Guide to Trade Unions and Works Councils,

Baker \& McKenzie, https:/ / digitalcommons.ilr.cornell.edu/cgi/viewcontent.cgi?arti cle=1048\&context=lawfirms, at 107-108; See supra note 134, at 42; Carol D. Rasnic, Germany's Statutory Works Councils and Employee Codetermination: A Model for the United States, 14 Loy. L.A. Int'l \& Comp. L.J. 275, 300 (1992).

${ }^{118}$ Jevtić, Milan. "The role of works councils and trade unions in representing interests of the employees in EU member states.", at 12 (2012).

${ }^{119}$ See supra note 117, Baker \& McKenzie, at 98.

${ }^{120}$ See supra note 118.

${ }^{121}$ See supra note 119.

122 Bruegel, Codetermination: Boosting cooperation between management and employees,_World Economic Forum, https:/ / www.weforum.org/agenda/2016/10/codetermination- 
workplaces, the works council can exist together with trade unions. A work agreement, which is made by a works council and an establishment, may contain work rules, working hours, the methods of payment, accident prevention, health protection, structure and administration of fringe benefits, the introduction to technical devices for monitoring employees' performance, and any other issues related to the employees' place of work. ${ }^{123}$ According to the compulsory conciliation proceeding of the Works Constitution Act (BetrVG), when it is difficult to create a works agreement, the conciliation board can settle any disputes. ${ }^{124}$ The conciliation board consists of a labor judge (as an independent chairman) and an equal number of representatives from the employer and the works council. ${ }^{125}$ The final decision of the conciliation board is binding unless the board goes against general principles and exceeds its discretion under the laws. ${ }^{126}$

The works council can require companies to comply with a works agreement enforced by the decision of an establishment-level arbitration committee; however, the establishment-level arbitration committee will recognize the priority of a collective agreement over a works agreement related to the same collective matters. That is to say, the collective agreement takes priority regardless of whether or not the establishment is bound by the collective agreement. ${ }^{127}$ The Federal Labor Court held that the trade union can stop the establishment from implementing the works agreement if the works agreement is not in compliance with the provisions of the collective agreement at the establishment level. ${ }^{128}$

In practice, many establishments are covered by a collective agreement, or they are governed by the works council with a collective agreement as a guide. The works councilors have a majority in a collective bargaining committee. The interactions between trade unions and works councils are as follows: first, the works councilors influence the workers' attitudes on the right to strike at the company level, which then also influences trade union policy; ${ }^{129}$ second, trade unions can represent the works council in labor courts if at least one work councilor is also a trade union member; ${ }^{130}$ third, trade unions have indirect impacts on the works council when more than $25 \%$ of the works councilors permit trade union officials to participate in the works council meeting; ${ }^{131}$ last, the works council and

boosting-cooperation-between-management-and-employees (last visited Dec.9, 2018).

${ }^{123}$ MITBESTIMMUNGSRECHTE DES BETRIEBSRATS CODETERMINATION RIGHTS OF THE WORKS COUNCIL, Eurofound, https://www.eurofound.europa.eu/efemiredictionary/codetermination-rights-of-the-works-council (last visited Sep. 21, 2020); See supra note 139 , at 11.

${ }^{124}$ See supra note 117 , at 109.

${ }^{125}$ See supra note 117.

${ }^{126} \mathrm{Id}$. at $109-110$.

${ }^{127}$ See supra note 123. the trade union worked together to mitigate conflicts over wage demands for years before and after the crisis. ${ }^{132}$

As opposed to the work councilors, the supervisory board guarantees the workers' right to participate in companywide questions related to economic planning and decision making. Also, the board gives workers the right of codetermination that only exists in large companies. ${ }^{133}$ The supervisory board members were selected by employee representatives and shareholder representatives. According to the One-third-participation Act (DrittelbG), if there are more than five hundred, but less than two thousand, regular employees in a stock corporation ("AG"), the company should have a supervisory board with one third of the seats filled by the employees' representatives in the company. Then, if there are more than two thousand regular employees in a stock corporation ("AG") or more than five hundred in a limited liability corporation ("GmbH"), the company should have a supervisory board with one half of the seats filled by the employees' representatives. ${ }^{134}$

\section{IMPLICATIONS}

In the pandemic, Chinese collective bargaining system is under the state control only for unionism and collective contract coverage, while less effective support from the central government in the light of labor laws. However, workers' representative can be grassroots trade union, or workers' representative can be a certain group of employees via democratic election process if there is no grassroots trade union in the light of Provisions on Collective Contracts 2004. Unlike the U.S. and Germany, the Chinese workers can be represented by non-union group in the process of negotiation. It seems like workers are more easily to bargain with their employer on a table, but insufficient labor laws deviated the story to another way. Worker-driven negotiation normally cannot bargain with their employer at first time; thus, worker-driven strikes exchanged a seat in the bargain table. In the light of Article 27 of the Trade Union Law, if strikes or work slowdown occurred in a plant, the trade union shall represent the employees to negotiate with their employer. This article is confused because if there is no union in a plant, workers have their representative via democratic election and then the representative can negotiate with the

\footnotetext{
${ }^{128}$ See supra note 117.

${ }^{129}$ See supra note 108 , at $42-44$.

${ }^{130}$ See supra note 117 , at $110-111$.

${ }^{131} \mathrm{Id}$.

${ }^{132}$ See supra note 108 , at 42 .

${ }^{133}$ See supra note 115.

134 Works Councils/Employee Participation, Zeller Seyfert, http://zellerseyfert.com/en/works-councils-employeeparticipation.html?gclid=CjwKCAjw5ZPcBRBkEiwAavvk4CINnKkSiycLwgQG_uwz4ikYYwbphQ5Mwf3zmxjNMx3 Y_zPS3wiLhoC7soQAvD_BwE.
} 
employer for their offensive demands for interests. But if the negotiation failed along with strikes or slow-down, the union shall represent the employees to negotiate.

The industrial peace depends on the enforcement of collective agreement and the choice of bargaining model. The labor laws in China, the United States and Germany provide relatively different bargaining power for unions and employers. China state corporatism creates a high trade union density and a broad coverage of collective contracts. Labor laws leave a room for bottom-up worker-driven negotiation. The laws also leave a room for the legality of the right to strike. However, Chinese workers' bargaining power has not enhanced via labor laws. Same with the United States, China uses company-level bargaining model which facilitate fragmented bargaining. The nature of state corporatism impedes intensive government intervention in guiding collective bargaining, while Germany with neocorporatism adopted sector-level and company-level bargaining models and promoted regulatory reforms to mitigate decentralization and fragmentation.

Given to industrial sectors, the low-wage competition induces factories relocate in low costs developing countries, thus the United States unions' bargaining power inevitably decreased in labor-intensive plants due to the globalization. However, the globalization made less influence on Germany which focuses on capital-intensive industries. The real challenge is the new information technology for Germany, the advantage of American manufacturing is the high-density innovation supported by venture capital in which Germany may be less competitive. With the pandemic spiral, flexible employment has increased, but the narrow definition of employee under the labor laws has excluded a larger share of the workforce. Under this condition, U.S. workers are unlikely to be gathered for their rights and interests. Even though Germany has a third type workers called "employee-like workers" which are protected in terms of certain parts of social security laws, these workers also cannot establish union and bargain with their employers. Thus, rethinking the definition of employee probably will provide workers more bargaining power to bargain with employers who shift production to low-wage workers overseas.

China's export-led growth model had challenged by laborcost increases, companies had been either to devote to wage increases, or to relocate to lower labor cost areas. Moreover, China is facing an unprecedented global backlash that could result in losing it's the world factory position. The industrial peace has become a hot-button issue and one of main task for government in respond for down-turn economy. As for labor-intensive factories, worker-driven negotiation and strikes may enhance bargaining power through the current collective bargaining system when labor supply cannot satisfy labor demand. Once the negotiation failed, workers have to be represented by a union in terms of current labor laws, which diminished workers' bottom-up power. The Labor Law should guarantee a good faith bargain from four aspects: exchange information, the duty to bargain and unfair labor practices, the mandatory subjects of bargaining and permissive subjects of bargaining, and remedies for bad faith bargain. The Labor Laws should clarify unfair labor practices with respect to good faith bargaining and the "relevancy" standard for furnishing information. The mandatory subjects of bargaining should be relevant to unions' duties in the collective bargaining, which directly impacts the wages, hours, and working conditions. Although an employer does not need to bargain with a union or workers' representative about the management decisions, simply subcontracting with respect to the terms and conditions of employment should be considered a mandatory subject of bargaining. Partial closure should be considered as a mandatory subject of bargaining, if the reason for closure is simply saving labor costs. Additionally, the administrative judge dockets should be established in the labor administrative agency, and the remedies for such refusals can be enhanced not only through a bargaining order but also through traditional remedies and extraordinary remedies by the labor administrative agency. Moreover, damage remedies for refusals to bargain can be enhanced in the courts.

As for capital-intensive industry, workers are easily to be replaced by machines. Thus, workers and strikers in capitalintensive industry are hardly to gain bargain power through the current collective bargaining system. Further, the lessen enforcement of collective contract allows trivial negotiation even though under the life of an existing collective contract. From one side, if workers raise a negotiation on wage increase and/or other working conditions during the life of collective agreement, it impedes industrial peace and, in the meanwhile, makes business environment worse for investors. From the other side, if the employer wants to a negotiation during the life of contract due to underperforming business, it hinders industrial peace and harms to workers' rights in the life of contract. Therefore, it is very significant to enhance self-govern in workplace through the grievance procedure and enforce collective contract through no-strike clause. The no-strike clause should be implied or expressed concluded in a collective contract on condition that the economic strikes and unfair labor practice strikes are clearly regulated in labor laws.

\section{How to Cite this Article}

Sun, X. (2020). China Collective Negotiation in COVID-19: What We Learn from a Comparative Analysis of China, the United States and Germany. American Journal of Trade and Policy, 7(2), 51-64. https://doi.org/10.18034/ajtp.v7i2.486 